$\left(\begin{array}{l}\text { Jpn. J. Hosp. Pharm } \\ \text { 24(6) } 704-710(1998)\end{array}\right)$

\title{
処方オーダにおける用法入力標準化のための現状分析
}

\author{
清水秀行 ${ }^{*} \dagger^{1}$, 土屋文人 $\dagger^{1}$, 神出英男 $\dagger^{2}$, 荒木基晴 $\dagger^{2}$, 永井 $\quad$ 肇 $\dagger^{2}$ \\ 帝京大学医学部附属市原病院薬凨部 $\left.\right|^{1}$ \\ NEC 医療システム事業部 $\dagger^{2}$
}

\section{Standardization of An Inputting Method for Direction Data in a Prescription Ordering System}

\author{
HIDEYUKI SHIMIZU ${ }^{*} \dagger^{1}$, FUMITO TSUCHIYA $\dagger^{1}$, HIDEO KAMIDE $\dagger^{2}$, MOTOHARU ARAKI $\dagger^{2}$ and HAJIME NAGAI $\dagger^{2}$ \\ Department of Pharmacy, Teikyo University School of Medicine lchihara Hospital $\dagger^{1}$ \\ NEC Medical Systems Division $\dagger^{2}$ \\ $\left(\begin{array}{ll}\text { Received February 3, } 1998 \\ \text { Accepted August 11, } 1998\end{array}\right)$
}

To standardize and develop a convenient inputting method for prescriptions, the frequency and directions of use were examined in an ordering system. A total of 552 kinds of directions have so far been registered on our system. However, 250 derections $(45 \%)$ had not been used for 1 month. The probability of selecting some directions on the first guide screen was analyzed. Of the drugs used, $95 \%$ of internal and $96 \%$ of external drugs could be prescribed on the first guide screen. The directions consisted of words and phrases, and these were classified into 4 types of information, how to use, how many times, when and where to use the medication. Based on our results, we also evaluated the inputting method.

Key words - standardization, prescription, ordering system, directions of use, inputting method

\section{はじめに}

処方オーダリングシステムの導入により，処方 せんに形式上不備の無い用法記載がなされるよう になった.しかし, システムの機能が医師の処方 行為と必ずしも一致しておらず, 医師の入力時の 負担が大きいといわれている．当院のシステムに おける用法の入力様式はメニュー選択方式であ

†1 千葉県市原市姉崎3426-3；3426-3, Anegasaki, Ichihara, Chiba, 229-0111 Japan

$\dagger^{2}$ 東京都港区芝5-29-23；5-29-23, Shiba, Minatoku, Tokyo, 108-8420 Japan
り， 1 画面に表示しきれずに 2 画面，3 画面にわ たる場合があり, 処方時の利便性に劣ることが危 惧されたそそこで，著者らは 1 画面で参照可能な 汎用性のある入力形態を構築するための基礎的な 研究として, 現行システムでの用法の使用頻度を 調査分析し，問題点について検討した。

\section{当院システムの用法ガイド画面の構成}

当院処方オーダ（NEC52オーダ）における用法 の入力様式と問題点の概要を表 1 に示す. 本シス テムは剤形コード別に用法ガイド画面を有す る. 552種の用法コードが46の用法ガイド画面に 
表 1. 当院処方オーダ（NEC52オーダ） における用法の入力様式と問題点

○人力様式

・ メニュー選択方式

・ 1 画面最大 42 コードを表示可能

・登録されている用法コードの数 552コード

・46のガイド画面に延べ981件の用法を表示

○問題点

・内服薬, 坐薬では 3 画面, 点眼液等の 100 外用 鼡では 2 画面の検索が必要

$\rightarrow 1$ 画面で検索可能な用法入力様式の検討

延べ981件登録されている．本システムで 1 画面 に表示可能な用法の数は最大 42 件であり，内服薬

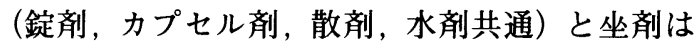
場合によっては第 3 画面を参照する必要がある.

用法の表示の配列はシステム自体に学習機能がな いため，使用頻度は特別には配慮されていない。 また，診療科あるいは医師ごとの用法セット機能 は装備されていない。

\section{調 査の 部}

調查の概要を表 2 に示す.

\section{1. 用法の使用頻度調査}

1 ) 調查対象: 平成 8 年 8 月の帝京大学医学部 附属市原病院の外来, 入院の全オーダリング処方 せんとした。

2 ）分析方法：内服・外用別, 診療科別, お上 び医師別に使用頻度一覧を出力し解析した。

\section{2. ガイド画面内包含率の調查}

複数のガイド画面をもつ内服薬（錠㓮・カプセ ル骭, 散剤, 水剂共通) および外用薬（点眼剤,

表 2 。調查の概略

(1)対象：外来・入院オーダリング処方せん

(2)期間：平成 8 年 8 月分

(3)処方せん枚数：23,325枚

件数 : 54,733 枚

(4)分析方法：

(1)用法の使用頻度調査

(2)ガイド画面内包含率の調査
坐剤等11鼡形）について，第一ガイド画面により 入力可能であった比率を包含率として調査した.

\section{結果および考察}

\section{1. 用法の使用頻度調查}

対象としたオーダリング処方せんは23，325枚で あった．用法の指示は処方件数ごとに発生するた め, 処方件数が母数となる. 処方件数は 54,733 件，内訳は，内服薬（頓服を含む）42,606件，外 用薬 11,736 件，自己注射薬（注射器，試験紙を含 む）375件および治験薬16件であった.

内服薬において使用頻度が高かった用法を表 3 に示す。「1日 3 回食後」の指示が最も頻度が高 く, 内服薬の総処方件数の $36 \%$ 占めた.「1日

表 3 ．使用頻度の高かった用法(内服薬)

\begin{tabular}{lcc}
\hline \multicolumn{1}{c}{ 用 法 } & 使用頻度 & (比率) \\
\hline 1 日 3 回食後 & 15382 & $36 \%$ \\
1 日 2 回朝夕食後 & 8725 & $20 \%$ \\
1 日 1 回朝食後 & 5130 & $12 \%$ \\
1 日 1 回ねる前 & 3369 & $8 \%$ \\
1 日 3 回食前 & 1464 & $3 \%$ \\
1 日 1 回夕食後 & 911 & $2 \%$ \\
1 日 2 回朝食後ねる前 & 894 & $2 \%$ \\
1 日 2 回朝食前ねる前 & 646 & $2 \%$ \\
1 日 1 回朝食直後 & 640 & $2 \%$ \\
1 日 4 回食後ねる前 & 433 & $1 \%$ \\
\hline 上位10件 合計 & 37594 & $88 \%$ \\
\hline
\end{tabular}

表 4 . 使用頻度の高かった用法（外用薬）

\begin{tabular}{lcc}
\hline \multicolumn{1}{c}{ 用 法 } & 使用頻度 & (比率) \\
\hline 医師の指示通り & 944 & $8 \%$ \\
1 日 2 回塗布 & 804 & $7 \%$ \\
両眼 1 日 3 回 & 641 & $5 \%$ \\
両眼 1 日 4 回 & 515 & $4 \%$ \\
痛い時 & 480 & $4 \%$ \\
両眼 1 日 2回 & 447 & $4 \%$ \\
適宜 & 431 & $4 \%$ \\
1 日 1 ～2 回塗布 & 346 & $3 \%$ \\
1 日 2 3 回塗布 & 337 & $3 \%$ \\
1 日 2 回 & 320 & $3 \%$ \\
\hline 上位10件 合計 & 5265 & $45 \%$ \\
\hline
\end{tabular}


2 回朝夕食後」は20\%であった.上位 10 件の用法 で全体の88\%を占めることが示された. 1989年に 高知医科大学の見元ら ${ }^{1}$ は処方オーダシステムで 用いられた内服薬の用法は全用法の $67.2 \%$ 毎食 後（1 日 3 回食後）が占めたと報告している. 本 調查で 1 日 1 回あるいは 2 回の服用指示の頻度が 高かったことは, 近年, 患者の良好なコンプライ アンスを得るために作用時間の長い持効性製凨の 開発が進んだことに起因していると考えられる.

外用薬において使用頻度が高かった用法を表 4 に示す. 外用薬の用法の使用頻度は剤形の処方頻 度に関係する. 処方頻度の高い軟衰剤, 点眼剤の 指示が上位を占めた. 最も頻度の高かった「医師 の指示通り」は15の剂形コードで使用されていた ためと考える。また，上位10件の合計で $45 \%$ を占 めることが明らかになった. 内用, 外用をあわせ た全552種の用法のうち250種（45\%）は調查期間 中一度も使用されなかった。

近年, 保険診療においては「医師の指示通り」 あるいは「用法口授」の指示は指示の内容を確認
しその旨を処方せんに記載するよう指摘されてい る. 当院では用法マスターからこれらのコードを 削除することを予定している。

縦軸に使用頻度の累積百分率, 横軸に用法の数 をとったパレート図を示す（図1）。内服薬では 使用頻度の高い23の用法で95\%のオーダが可能で あり, 外用薬の用法は多岐にわたることが予想さ れるが，80の用法で95\%のオーダが可能であるこ とが確認された。

次に, 内服薬の用法の使用頻度を診療科別に集 計したパレート図を示す (図 2). 診療科により パターンは異なるが，95\%のオーダが可能な用法 の数は最も少ない整形外科では 7 , 最も多い外科 においては17であった.

また，内科医師81名を対象に医師別に内服，外 用を合わせた使用用法数を解析したところ, 最大 值は91であり，中央值は33であった（図 3 ).内

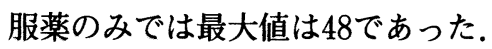

\section{2. ガイド画面内包含率の調査}

各ガイド画面での包含率を表 5 に示す．第一ガ

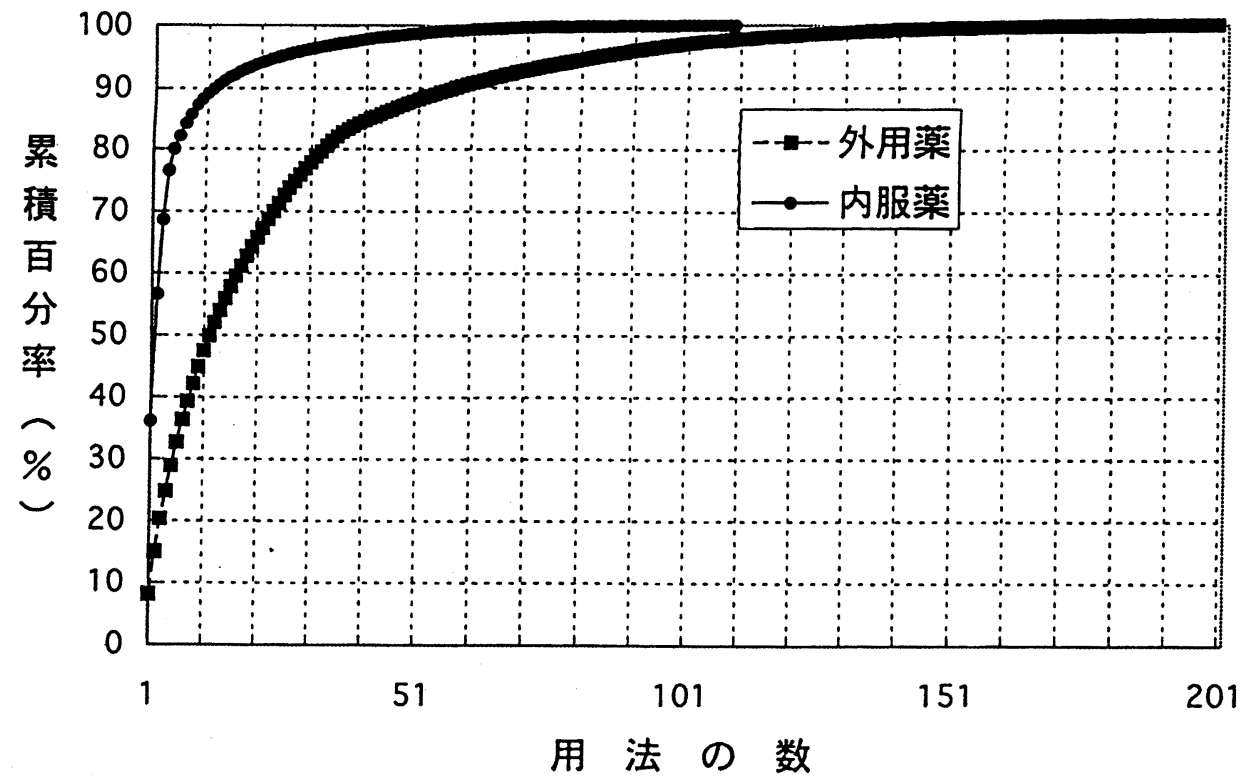

図 1. 用法の使用頻度の累積百分率

（内服薬用：110種, 外用薬用：200種） 


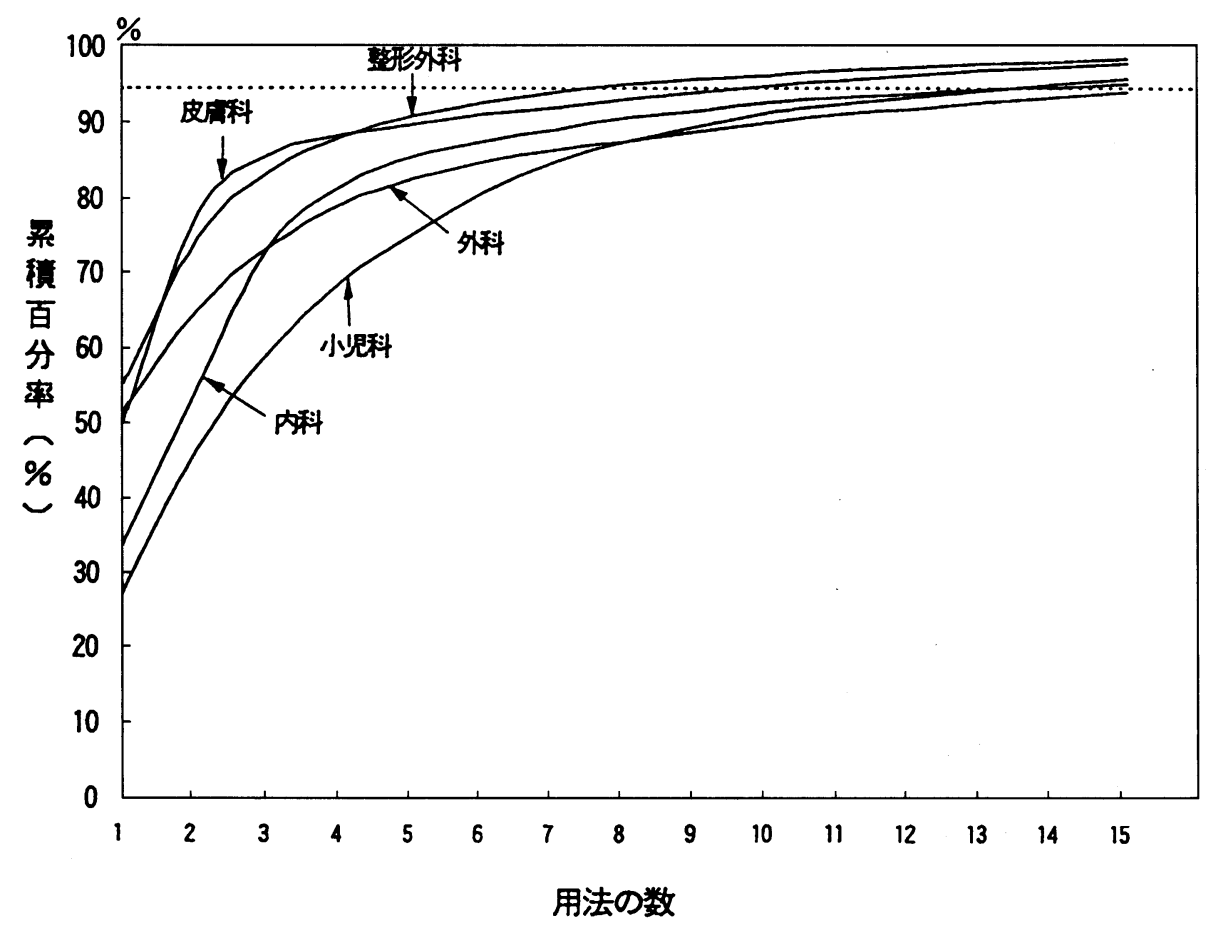

図 2, 用法の使用頻度の累積百分率

（15診療科より 5 科を選択）

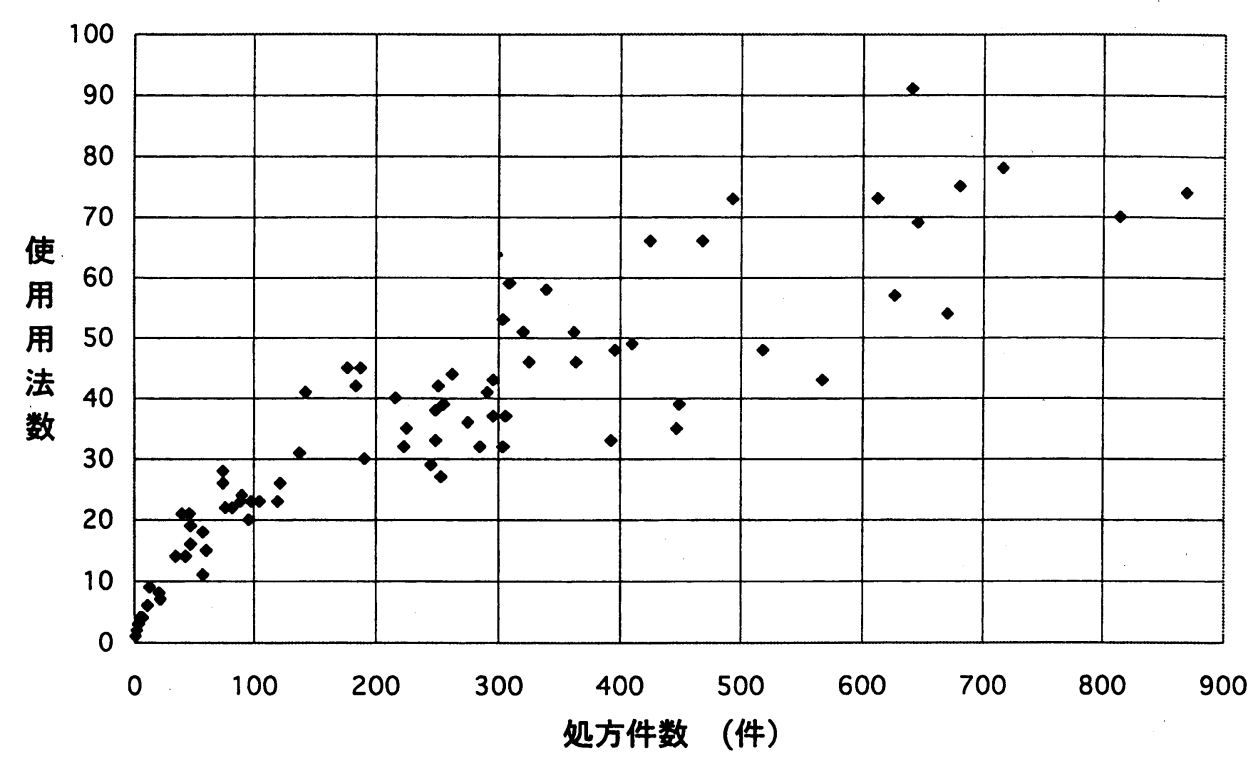

図 3.内科医師における処方件数と使用用法数との関係 (医師数：81名) 
表 5 . ガイド画面の包含率

\begin{tabular}{clccrr}
\hline 区 分 & ガイド画面 & 画面数 & 表示用法数 & 使用頻度 & 包含率 \\
\hline \multirow{6}{*}{ 内服薬 } & 第一 & 1 & 34 & 39577 & $95 \%$ \\
& 第二 & 1 & 36 & 259 & $1 \%$ \\
& 第三 (頓服) & 1 & 36 & 1689 & $4 \%$ \\
\hline \multirow{2}{*}{ 外用薬 } & 合計 & 3 & 106 & 41525 & \\
& 第一 & 11 & 293 & 6034 & $96 \%$ \\
& 第二 & 11 & 201 & 241 & $4 \%$ \\
& 第三 & 1 & 25 & 0 & $0 \%$ \\
\hline & 合計 & 23 & 519 & 6275 & \\
\hline
\end{tabular}

表 6 . 使用されている語句の分類

\begin{tabular}{|c|c|}
\hline $\begin{array}{l}\text { 適用方法 } \\
\quad \text { (塗布, 点眼, 点耳など) }\end{array}$ & 16語句 \\
\hline $\begin{array}{l}\text { 適用回数 } \\
\qquad(1 \text { 日 } 1 \text { 回, } 1 \text { 日 } 3 \text { 回, 頻回など })\end{array}$ & 29語句 \\
\hline $\begin{array}{l}\text { 適用時期 } \\
\text { （朝，食後，痛む時など） }\end{array}$ & 82語句 \\
\hline $\begin{array}{l}\text { 適用部位 } \\
\text { (右眼, 左耳, 口の中など） }\end{array}$ & 20語句 \\
\hline
\end{tabular}

イド画面による包含率を内服薬と外用薬とにわけ て集計した結果，内服薬では95\%，外用薬では 96\%であった．現行では第一ガイド画面に表示す. る用法の配列に使用頻度を考慮していないにもか かわらず内服薬, 外用薬ともに高い包含率であっ た。

3. 登録されている用法に使用されている用語の 解析

登録されている552種の用法に使われている語 句を分類集計した（表6). 語句は概ね適用方 法, 適用回数, 適用時期, および適用部位の 4 つ の情報に分類され，合計147の語句により構成さ れていた。したがって，これら 4 つの情報を逐次 入力することにより必要とする用法を検索するこ とが可能であると考えられた。

\section{4. 逐次入力様式の検討}

以上の結果をふまえ，メニュ一選択方式に医師 別セット機能及び学習機能をもたせ, かつ逐次検 索機能をあわせもった入力方式を検討した。
図 4 に特定の内科医師の用法ガイド画面を示 す.メニューに表示されている用法は本調查で実 際に医師が使用した用法を服用回数と時期により ソートして作成した。 上部に逐次指示選択用の入 力欄である「回数選択欄」を設けた. 医師はメ ニューの項番を選択することにより沉用する用法 の入力が可能であり, 頻度の少ない用法は逐次検 索機能により入力が可能となる.

図 5 に逐次検索機能により服用回数 [3] を選 択したところを示す．項番01から05におよその時 期を示す時期 [1] が表示される.

図 6 に時期 [1] として項番 [03] 朝, 夕, 寝 る前を選択した状況を示す。この選択により食 前, 食後などの時期 [2] の選択画面が展開さ れ，時期 [2] を選択し用法の入力を終了する.

逐次入力様式では, 医師は回数, 時期, 部位の 順で入力を進めることで手書き処方せんの感覚を もつことができる。また，用法マスターには適用 方法, 適用回数, 適用時期, および適用部位個々 の情報を登録するのみで，それらの組み合わせを 考える必要がないことから, 処方時の使用性およ びシステムの保持管理の利便性にすぐれた汎用性 のある入力方法であると考える.

$$
\text { ま と め }
$$

当院の用法マスターに登録されている用法の半 数近くが調査期間中 1 度も使用されておらず, 無 駄の多いマスター構成となっていたことが明らか 
内科 D r. XX（用法指示内容回数順＆逐次検索機能ウィンドウ その1）

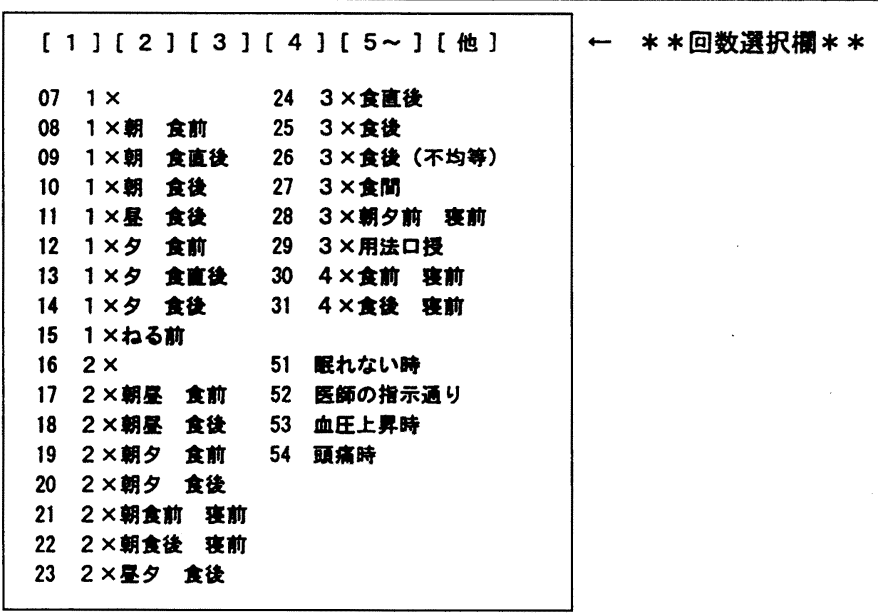

図 4. 逐次入力機能付きメニュ一選択式入力画面 その 1

解説：使用頻度の高い用法を適用回数と時期を考虑して並べ替えた

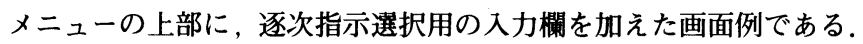

逐次指示選択は [回数] $\rightarrow$ [時期 1] $\rightarrow$ [時期 2] $\rightarrow$ [部位 $]$ の順で行う.

内科 D r. Xx（用法指示内容回数順＆逐次挨索機能ウィンドウ その 2)

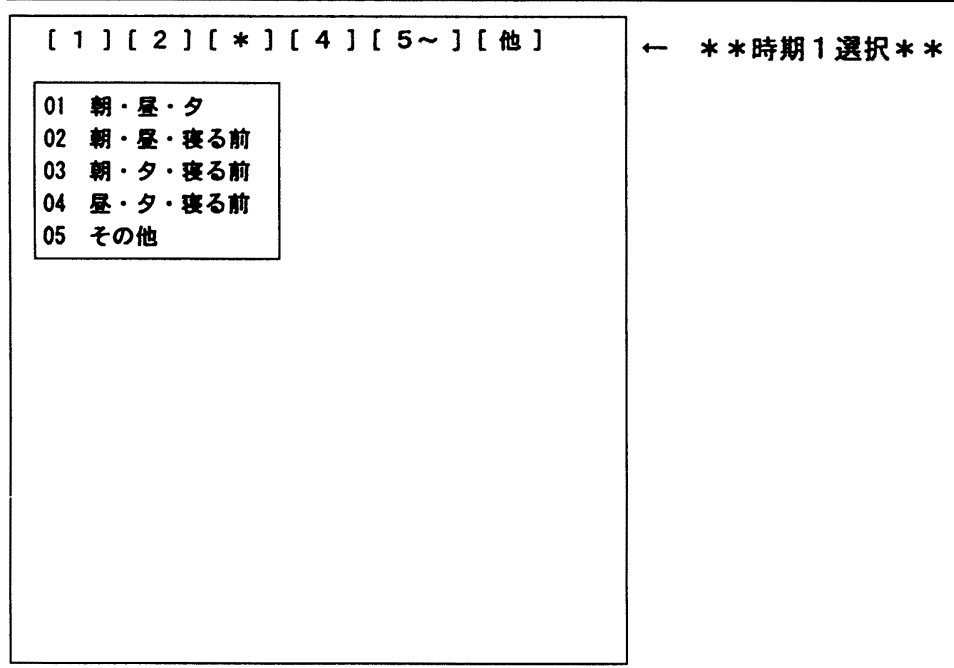

図 5. 逐次入力機能付きメニュ一選択式入力画面 その 2

解説：適用回数 [3] が選択されたので, その回数に対応する

[時期 1] の指示内容を表示した画面例である. 
内科 D r. . X X (用法指示内容回数順 \&逐次検索機能ウィンドウ その3)

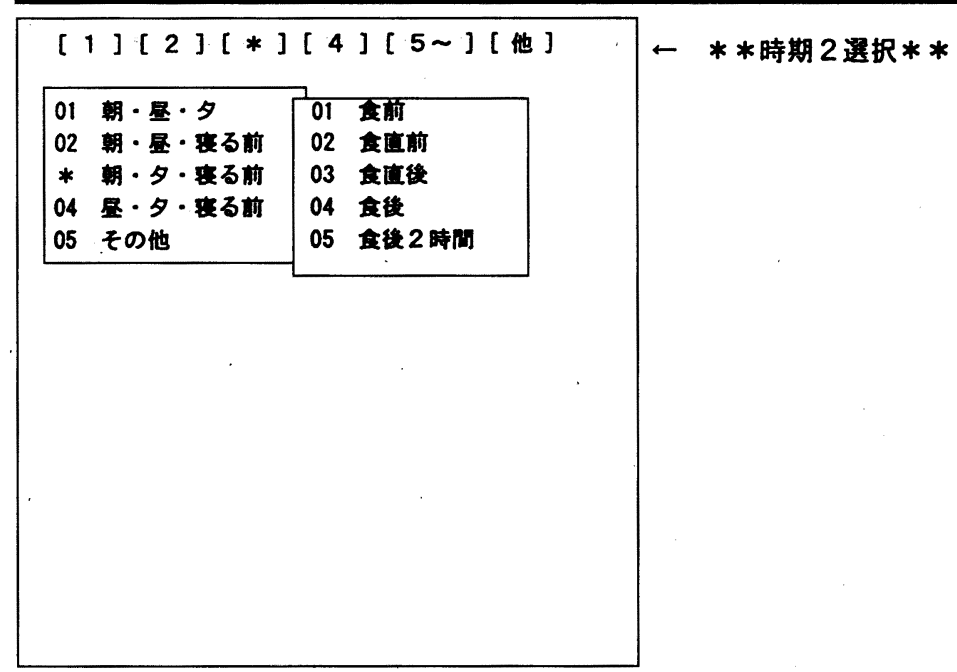

図 6. 逐次入力機能付きメニュ一選択式入力画面 その 3

解説：[時期 1] から「朝・夕・寝る前」が選択されたので, その時期に対応 する [時期 2 ] の指示内容を表示した画面例である.

になった。用法は概ね適用方法, 適用回数, 適用 時期，および適用部位の 4 つの情報の組み合わせ で構成される場含が多い。したがって，4つの情 報を順に入力することによりハイパーテキスト形 式に画面を展開することが可能である，画面構 成, 画面の展開方法など今後詳細に検討する必要 はあるが，使用頻度の高い用法はメニューによる
入力, 頻度の低い用法は逐次検索による入力が可 能な本システムは, 処方時の使用性およびシステ ムの保持管理にすぐれた汎用性のある入力方法で あると考える。

\section{引用文献}

1) 見元尚, 西岡豊, 月刊薬事, 31, 153-158 (1989). 